Pakistan Journal of Social Sciences 9 (5): 238-245, 2012

ISSN: $1683-8831$

(C) Medwell Journals, 2012

\title{
Foisting a Willing Employee on an Unwilling Employer: The Remedy of Re-Instatement Revisited
}

\author{
Kola Odeku and Sola Animashaun \\ Faculty of Management and Law, University of Limpopo, \\ 0727 Turfloop, South Africa
}

\begin{abstract}
The irrepressible sage Voltaire stated in one of his treatise Candide in (1759) that work spares us three major evils; vice, boredom and need. This statement is true today as it was centuries ago when it was first made. In Nigeria, just as any other developing countries, people work in order to live that is to satisfy needs and wants. Work is essentially an important social economic issue. If a member of the family who was gainfully employed is retrenched, this will have reverberating effect on the family and the larger community as a whole. This is so mainly because of the extended family ties system since there is no provision of any form of welfare in the majority of the African countries. This study examines the way and manner employers dispensed with the employees in the workplace and the remedies available to the employees in cases of wrongful, unfair dismissals or termination of appointment. The study analyses the dichotomy between the employees with statutory flavour or special status and those who are mere servants. The study also examines critically, judicial activisms regarding re-instatement in light of unfair and wrongfully termination of employment by considering approaches from other jurisdictions.
\end{abstract}

Key words: Contract of employment, termination of employment, vulnerability of employees, judicial intervention, reinstatement, Nigeria

\section{INTRODUCTION}

The major thrust of industrial relations is the differing interest of the two actors and the endemic conflict which it originates (Animashaun and Shabi, 2009). The employers are interested in extracting long hours of service and paying the employee as low as possible. The employees on their part are interested in high wages for lesser work. That is, the employers are interested in high profit by extracting long hours and low pay while the employees are interested in eating into the employers' profit. The employer in the quest to make more profit terminates the employment of their employees in order to avoid certain obligations.

There are many instances of wrongful and unfair termination of employment. In many cases the employer suspends the employee indefinitely. After endless wait the employees applied to court for a declaration that they are still in the employer's service. In Nigeria, such employees are usually in precarious situations as they do not know whether reinstatement will be ordered by the court or not. This is exacerbated by the fact that contradicting conclusions are reached in the courts with regards to cases with similar facts.

\section{BASIS OF EMPLOYMENT RELATIONSHIP}

The basis of employer-employee relationship in most part is the contract of employment and the ordinary incidents of that relationship. The contract of employment which is the plank of the relationship is however of product of industrial revolution and the 19th Century laissez-faire is its principal justification (Adeogun, 1986).

The 19th century laissez faire rested on two legs, the freedom of the contracting parties and the sanctity of contracts. The court considered it their bounden duty to foster the freedom and vindicate its sanctity. The dictum of Sir George Jessel in the case of Printing and Numerical Registering Co. v Sampson in 1875 is apt here:

If there is one thing more than another which public policy requires, it is that men of full age and competent understanding shall have the utmost liberty of contracting and that their contracts, when entered into freely and voluntarily shall be held sacred and shall be enforced by the court of justice

Bentham, commenting on the same idea posited:

Corresponding Author: Kola Odeku, Faculty of Management and Law, University of Limpopo, 0727 Turfloop, South Africa 
No man of ripe years and of sound mind, acting freely and with his eye open ought to be hindered with a view to his advantage from making such a bargain in the way of obtaining money as he thinks fit nor (what is a necessary consequence) anybody hindered from supplying him, upon any term he thinks proper to accede to

In the case of Olaniyan v University of Lagos in 1985 2 NWLR 559 at 669, Justice Karibi-Whyte endorsing the dicta above stated that contracts of employment like other contracts, their creation and termination are both subject of the general principles governing the law of contract. Hence, when the contract is in writing the parties are bound by the express terms and conditions so stipulated.

The dicta above shows that individualism is sanctioned as a value in itself and also as a means of social mechanism (Animashaun, 2007). Despite the fact that judges in this jurisdiction and greatly impressed by Sir Jessel's statement, they failed to heed caution expressed even during the golden age of laissez-faire. Jessel cautioned that only men of full age and understanding who had contracted freely and voluntarily could expect the court to hold their contracts sacred and have them enforced.

The questions are: does the contract of employment in Nigeria satisfy the above requirements? Are the parties free and equal in all respect? Or in any respect at all? Do the employer and the employee have equal bargaining power? (Adeogun, 1986) offered appropriate responses to these questions and said that equality of the parties and the freedom is a mirage. More importantly, he gave very cogent reason for the vulnerability of the employees during the time of negotiating employment contract. In his words, he stated that:

This thesis presupposes equality between the parties but tend to ignore other social and economic considerations which may make this equality and its underlying freedom fictitious and hollow the economic necessity which may compel an employee to accept a contract of service is not the concern of law

Against the above backdrop, Adeogun revealed the vulnerability of the aspirants' workers in the developing countries, particularly in Nigeria where many workers (multitude) are chasing the few available job opportunities. What is important to the job seekers at the point in time is to secure the job irrespective of the terms and conditions inherent in the offer of appointment. The reason for this is that usually, the job is needed by the applicant with a lot of desperation in order to make ends meet by solving pressing socio economic challenges. At the same time a lot of people are also looking for the same job. Consequently, the applicant is ready to waive, mortgage or foreclose all his right at the point of accepting the offer. What is of paramount importance at that point in time is to secure the job. This explains the plight of applicants and supplicants in the developed countries.

The earlier synarios is exacerbated by population explosion, bad governance, restructuring, downsizing, privatization, commercialization, globalization and more recently global recession (Animashaun and Shabi, 2009). There have been instances of over twenty thousand qualified candidates responding to an advertisement by a firm that had only five vacant positions. The question to ask at this juncture is where is the much taunted equality between the parties.

\section{EXPLANATION OF MASTER AND SERVANT RELATIONSHIPS}

To come properly within the purview of labour law, it must be shown that a relationship of master-servant exists between the parties (Emiola, 2000). This is because labour law applies mainly, although not exclusively to masterservant relationship. There is a great deal of difficulty in defining the term servant at common law, this made Thesiger L.J. to note in Yewens versus Noakers in 1890 that definitions are proverbially dangerous Thus, devices such as control Kuti versus Jibowu in 1973, multiple factors O'Kelly versus Trust in 1983, Integration Cassidy versus Min of Health in 1951 and economic reality Market Investigations Ltd. versus Min. of Social Security in 1968 tests are employed to determine employment relationship. However, Aguda J defined a servant as a person employed by another to do work for him on the terms that he, the servant is to be subject to the control and direction of his employer in respect of the manner in which the work is to be done' Esso WA Ltd. versus Alli in 1968.

Again, a servant has been variously defined in different ways in Nigerian statutes. The Workmen's Compensation Act cap 6 Laws of the Federation Nigeria in 2004 in Section 2, defines a workman as any person who has entered into or is working under a contract of service or apprenticeship with an employer whether by way of manual labour, clerical work or otherwise and whether the contract is express or implied, oral or in writing. The Trade Union Act Cap T 14 Laws of the Federation of Nigeria in Section 51, defines a worker as any employee that is to say any member of the public 
service of the federation or of a state or any individual (other than a member of any such public service) who has entered into or work under a contract with an employer otherwise expressed or implied, oral or in writing and whether it is a contract personally to execute any work or labour or a contract of apprenticeship.

It should be noted that the statutory definitions are rather restrictive. Researchers prefer to adopt the common law definition akin to the dictum of Aguda J in Esso W.A. Inc. v Alli in 1968.

There is also a need to distinguish between a mere servant and an exotic brand known as public servant as the latter enjoys a higher status than the former. A public servant has been described as a person employed in one of the services, promoted or supported wholly or largely by fund from the state treasury (Emiola, 2000). In Kadiri versus Apampa in 1980 the Supreme Court held that a person employed under a statute is a public officer. In AG Bendel State of Ors versus Okwumabua in 1980, it was held that by virtue of Section 271 (1) of the 1999 Constitution of the Federal Republic of Nigeria all public education institutions owned or controlled by the federal or state governments or its agencies are in, public service and all the staff of such institutions are public servants, Justice Kalu Anyah and Ors versus Dr. Festus Iyayi in 1993.

The status and implication of employment with statutory flavour in contradistinction with master-servant relationship was fully explored by Karibi-Whyte in Imoloame v WAEC in 1992 where he said that it is now accepted that where the contract of service is governed by the provision of statute or where the conditions of service are contained in regulations derived from statutory provisions, they invest the employee with a legal status higher than the ordinary one of masterservant. They accordingly enjoy statutory flavor.

The English Equal Rights Act (ERA) in 1996 aptly defined re-instatement order as an order that the employer treat the employee as if there had been no interruption in the employment contract. The employer will pay the entire amount due to the employee less any amount paid in connection with the dismissal (Malcolm, 2003). Reinstatement was define in Shitta-Bey v Federal Public Service Commission in 1981 as the natural and primary, meaning of, to reinstate as applied to a man who has been dismissed without justification is to replace him in the position from which he was dismissed and so to restore the status quo ante the dismissal. Section 115 ERA in 1996 went further to clarify the fine and rather subtle distinction between reinstatement and re-engagement. A re-engagement order is defined as an order that the employee be taken back by the employer into a position comparable to that from which the employee was dismissed or other suitable employment.

\section{WHAT IS REINSTATEMENT IN LABOUR DISPUTES?}

Reinstatement is one of the remedies open to victim of unjust or unfairly dismissed. Reinstatement can be ordered in addition to other remedies.

Re-instatement in private sector: The prevailing view among Nigerian judges is that the relief of reinstatement is available for confirmed pensionable employee whose contract is spiced with statutory flavor or where the person dismissed occupied a position with a special legal status Shuaibu versus Union Bank of Nig. Plc in 1995. For employees in private employment, re-instatement is only ordered when the employee is able to prove special circumstances, Chukwumah versus Shell Petroleum Devt. Co. of Nig., Ltd. in 1993 and that is at the discretion of the courts, NNPC versus Idoniboye-Obu in 1996.

The impression given by Nigerian judges is that re-instatement is an alien relief for private employees (Chianu, 2006). However, the decision in other common law jurisdictions such as the UK and India do not appear to support the attitudes of Nigerian judges.

The Indian Supreme Court awarded the remedy of reinstatement in Provincial Transport Services v State Industrial Court, Nagpur in 1963, Das Gupta J. advocated that although the court must recognize legal relationship based on contracts but regulated by a higher law. His dictum is aptly stated thus:

In dealing with industrial disputes, the Supreme Court have by a series of decisions laid down by the law that even though under contract law, pure and simple, an employee may be liable to dismissal without anything more, industrial adjudication would set aside the order of dismissal and direct re-instatement of the workmen when dismissal was made without fair enquiry

Likewise, in Hill versus C.A Parsons and Co. Ltd. in 1971, the Plaintiff/Appellant, aged 63 had been employed as an engineer for about 35 years. He was dismissed with a month's notice, not withstanding that he was due to retire in 2 years time. He applied for an interim injunction to restrain the company from acting upon the dismissal notice. He failed at the trial court but succeeded at the Court of Appeal where it was held that the Appellant case was extraordinary as he was liable to suffer dis-proportionate hardship if his contract was so determined. Compare the above cases with that of Friday Abalogu v Shell Petroleum Devt. Co. in 2003. The plaintiff/Appellant was employed in the defendant 
company on 3rd May, 1971. The appointment was confirmed on 3rd May, 1972. Thereafter, he became a permanent and pensionable staff of the company. By a letter on 25th January, 1995, he was notified that he was due to retire on 3rd August, 1996, his 55th birthday. However, by another letter of 31st, January, 1995 his appointment was terminated, paying him 3 months salary in lieu of notice. He claimed that the termination must be null and void as he was already due for retirement. He lost in all the courts.

The courts have consistently held that in a contract of service, a master is entitled to dismiss his servant for a good or bad reason or no reason at all, Osuma versus Edo Broadcasting Service in 2005. In Registrar and Trustee PPFN versus Shogbola in 2004, the contention of the Plaintiff/Respondent that his appointment was that with statutory flavour was rejected and the order of reinstatement by the trial court was upturned by the Court of Appeal. Similarly, although the court recognized the injustice of the termination of the appointment of 700 junior and 55 senior workers by the management, unlawfully and unjustly, still it refused to order reinstatement, it only awarded minimal damages. In Ezekiel v Westminister Dredging Ltd. in 2000, the trial court acknowledged that the termination of the plaintiff's appointment was wrongful but only awarded a month salary. However, the court of Appeal reversed the decision with regards to the damages payable, reducing this to 2 weeks salary as stipulated on the contract of service.

The courts have in extra ordinary cases ordered re-instatement especially where a special status such as where the tenure of public office is attached to the contract of employment, African Continental Bank Plc v Nwodika in 1996. The National Industrial Court also ordered re-instatement of the wrongfully dismissed workers in Hotel and Personal Services Senior Staff Association versus Owena Hotels Ltd. Akure in 2005 and NNPC versus Petroleum and Natural Gas Senior Staff Association of Nigeria in 1990. The decision in the latter case is not unconnected with the fact that NNPC is a government parastatal and that the staff of such parastatals should enjoy security of tenure. In Ewarami versus ACB in 1978, the Supreme Court granted a declaration that a dismissed worker is still in the employment of his employer and awarded substantial damage.

It is noteworthy to state that most jurisdictions had moved away from the days of Fry L.J. where re-instatement was a taboo. His statement in De Francesco versus Barnum in 1890 summarized his reasoning thus:
For my part, I should be very unwilling to extend decisions the effect of which is to compel persons who are not desirous of maintaining continuous personal relationship with one another to continue. I have strong impression and a strong feeling that it is not in the interest of mankind that the rule of specific performance should be extended to such cases, lest they should turn contracts of service into contracts of slavery and therefore speaking for myself, I should lean against the extension of the doctrine of specific performance and injunction in such a manner

This 19th century case is predicated on certain premises which are no longer applicable and the English judges have departed from refraining from re-instating a wrongfully or unfairly dismissed employee (Animashaun, 2008). Remedies following a finding of unfair dismissal by an employment tribunal are re-engagement, re-instatement or compensation (Animashaun, 2008). The employment tribunal has considerable discretion about making re-instatement order on the tests of practicability and justice. The tribunal will take into account the complainants wishes and whether it is practicable for the employer to comply with the order for re-instatement. It will also take into consideration whether such an order would be just in the circumstances where the employer contributed towards the dismissal.

In Rao v Civil Aviation Authority in 1992, an employee with extremely poor attendance record was dismissed. The dismissal was held to be unfair on procedural ground but the employment tribunal refused to order re-instatement or re-engagement because of his conduct. It only awarded damages. In Bigham and Keogh v GKN Quickform Ltd. in 1992, an employee working on a site was dismissed as a result of strike. Subsequently, he applied and successfully got a job at the employer's head office elsewhere. He revealed his previous employment but not the dismissal. After a few weeks the connection with earlier dismissal was made and he was dismissed from the new position. The tribunal ordered re-instatement as the employer had constructive knowledge of the employee's previous employment. The tribunal ordered reinstatement when a shop manager was dismissed unfairly because she asked the trade union for assistance against the management with regards to her rights in Discount Tobacco versus Armitage in 1990. Likewise an employee who was dismissed because he made derogative remarks about the company at a company recruitment meeting was reinstated. Also in Wood Group Heavy Industrial Turbines Ltd. versus Crossan in 1998, an 
employee was dismissed for a genuine belief by the employer that the employee has been dealing in drugs at the workplace. Although, the employment Tribunal ordered re-engagement due to the fact that the employer did not carry out sufficient investigation. On Appeal this decision was reversed and the complainant/respondent granted compensation because the court believed that there is a breakdown of mutual trust and confidence.

The English court declined to make a reinstatement order when economic condition of the company does not permit, for instance because of the worsening redundancy situation of the employer, Port of London Authority versus Payne in 1994.

If however the employer fails to reinstate or re-engage as a result of an order then the employee will be awarded compensation for unfair dismissal which will include additional awards such as loss suffered by employee as a result of non-compliance with re-instatement order. Section 166 Trade Union and Labour Relations Consolidation Act in 1992. Many legal writers and judges have reasoned that reinstatement is unsuitable in contracts of personal service. The basis of their reasoning and the inherent contradictions are discussed (Chianu, 2006).

First, they argue that once an employee is dismissed irrespective of the fact that the dismissal is wrongful the employment contract is automatically repudiated and the employee's only remedy should be damages, UTC Co. Nig., Ltd. v Nwokoruku in 1993. The matter may not be that simple. Certain contract terms survives the employment contract regardless of the supposed effect of a breach on the rest of it. For instance, employers are enabled to enforce restraint of trade clauses even after an employee has resigned or abandon his employment, Thomas Marshall (Exports) Ltd. v Guinle in 1978. Also, employers have rejected employee's resignation in many cases on the ground that they should first answer to charges of misconduct before they leave the employment and the courts have upheld such insistence, Graham Douglas v A.G. Rivers State in 1973. If the employer is at liberty to reject repudiation why should be court reject the order of reinstatement in the event of wrongful or unfair dismissal (Cartey, 1989).

Second, the courts, Oyedele v University of Ibadan in 1990 and legal writers basing their arguments on mutuality insisted that the court could not foist a willing worker on an unwilling employer and vice versa. This is based on equality principle and sanctity of contract. One could fault this reasoning on the disparate consequences to the parties. The departure of any employee in most cases constitutes a mere inconvenience, distraction or is barely noticed. However, on the part of an employee, a job loss usually leads to insecurity, poverty, health problems, striving for alternative employment, the use of dangerous drugs and engagement in social vices.

The third basis is that in contract of personal services, personal pride, personal feelings, confidence and confidentiality may be involved which made it undesirable to impose a willing employee on an unwilling employer (Ipaye, 1992). This reasoning have been criticized on the ground that most employers today run large, impersonal organizations involving many departments and hundreds or even thousands of workers. In these cases, issues of mutual confidence and personal pride may not arise. It was stated that in the nineteenth century when De Francesco case was decided, contract of service were chiefly between a farmer or an owner of a small workshop and his servant. A learned researcher Chianu (2006) posited that that era involves personal confidence and intimacy and this should be distinguished from the era of large informal organizations. Further more, in modern day employment both management and workers are employees as ownership is removed from management. Thus, it is a case of some privileged workers dismissing other workers.

The fourth basis is that the court assumed that once an employee is dismissed, the employers cannot rescind its decision. Thus, an order of reinstatement is only adding to the employer's burden. This premise had however been debunked by the Employer rescinding its decision on being pressured by trade union, the employee's legal practitioner or on being found innocent after an investigation, Afribank Nig. Plc v Nwanze in 1998. In Cooperative and Commerce Bank Nig., Ltd. v Nwankwo in 1993. The respondent was dismissed in November, 1975 on the ground of unethical banking practice of over lending. However, he was reinstated in February, 1996 following his appeal to the appellant's board. The above shows that there is a wide difference between the reasoning of the Nigerian judges and the industrial relation practice as the highlighted cases (and there are others) show instances whereby dismissed employee case is reviewed he is reinstated suo moto.

The strongest contention against re-instatement is the employer dismissing the employee afresh, Amokeodo v IGP in 1996. In Eyutchae versus Nigeria Television Authority, Eyutchae versus Nigeria Television Authority in 1986 the appellant was terminated and successfully sued to have this termination set aside. The respondent appealed but while the appeal was pending, the appellant was dismissed again. The Court of Appeal however felt its hands were tied by the second dismissal, AG Federation versus Roadside Engineering and Foundry Nig. Ltd. and Soteye. It is the contention here that the court should not 
indulge the employer in acting with impunity and that if they cannot order re-instatement or the employer is unwilling to retain the worker for no just reason, the court must be willing to impose a hefty award as aggravated damages to the employee as a deterrent.

\section{RE-INSTATEMENT IN PUBLIC SERVICE}

As earlier stated in this treatise, public employees whose contract of employment are spiced with statutory flavour or those with special status enjoy higher privileges. The court in most circumstances gave reinstatement order in these cases. The basis of this may not be unconnected with fact that while damages may be appropriate for enforcing individual rights, it does not adequately ensure that public bodies act within their power. Furthermore, the sum paid as damages does not come from the purse of the individual officer who made the rash decision to wrongfully dismiss a successful litigant/employee. Thus, the courts are concerned with vires of public authority and with the abuse of power or discretion.

The Chief Public law remedies are certiorari, injunction, mandamus and declarations. The court has consistently held that where a servant's employment is founded on statute or has statutory flavour and the appointment is not terminated in accordance with the procedure laid out in the statute, he will be entitled to automatic reinstatement, P.T.I and Ors v Nelsimone 1995.

The Supreme Court held that a court cannot make an order of specific performance unless a contract is shown to exist, F.A. Airewele v Refrigeration Engineer and Contractors Ltd. in 1980. Also, the party has performed his own part of the contract.

Secondly, the court claimed that it would not order specific performance when the contract has ceased to exist, for instance, when the post had been filled the court will be inclined to make the appropriate order. Thus, in Igbe $\mathrm{v}$ Governor of Bendel State and Ors, the court awarded damages in place of reinstatement because the post had already being filled. But in Olaniyan v University of Lagos, Shitta Bey versus Federal Public Service Commission and others, an order of re instatement was made. Thirdly, the court will not make the order where it will cause injustice to a third party.

In Ex parte Kubeinje the respondent, successfully applied for an order of certiorari to quash proceedings of the Mid-West State Public Service Commission that instructed him to accept a transfer to another post or consider himself summarily removed from the public service. The leading authority in Nigeria on the use of the remedy of mandamus in reinstatement is Shitta Bey versus
Federal Public Service Commission. However, in the case of Eperokun v University of Lagos, declarative remedy was used in reinstating a wrongfully dismissed public officer.

The decision in the case of Bakare v Lagos State Civil Service Commission in 1992 is noteworthy, bold and commendable. The court was neither swayed by the fact that the relationship between the appellant and his employer was strained, nor was it perturbed by the fact that the appellant's first claim was for damages, reinstatement being an alternative. In this case, the appellant was the Secretary of the Purchasing, Supplies and Maintenance committee of the Lagos State Schools Management Board. He observed certain irregularities and petitioned the Executive Secretary of the Board on receiving no reply he petitioned the governor and eventually the code of conduct Bureau. The governor met with him later and assured him that the investigation carried out revealed no irregularity. The next day, he was issued a query and redeployed a few weeks later. $\mathrm{He}$ refused to report at the new station for about a year. His salary was stopped and was issued a query on various misconducts including absence from duty without leave. $\mathrm{He}$ thereupon sued for unjustifiable repudiation of contract and sought damages or reinstatement. The Supreme Court awarded the alternative claim of reinstatement. This decision may not be unconnected with the fact that the appellant is seen by their Lordships as being against corruption the fact that he refused to report for duty for over a year notwithstanding. However, in Faponle versus University of Ilorin Teaching Hospital Management Board in 1991, the request to reinstate the appellant was refused when it was evident that he was guilty of disobedience and insubordination.

The court had held that the fact that the employer is a statutory body does not mean that the condition of service of its employees must be of a special character ruling out the relation of a mere master and servant, Udemah v Nigeria Coal Corporation in 1991. This had led to conflicting and confusing decisions in Ideh $\mathrm{v}$ University of Ilorin in 1994 where the appointment of a principal technical officer in the employment of the respondent was terminated with a month salary in lieu of notice. The court held that the appointment was not one with statutory flavour. Hence, respondent power was properly exercised.

However, in University of Calabar v Inyang, the appointment of a junior administrative staff (store assistant) was held to be of statutory flavour hence ordered to be reinstated, Adeniyi v Governing Council of Yaba College of Technology in 1993. Also, the appointment of a pharmacist in a University Teaching 
Hospital was held to enjoy statutory flavour and the court ordered her reinstatement. This privilege was denied a senior nursing sister in a similar establishment, Fakuade in 1993.

\section{ALTERNATIVE REMEDIES}

Award of damages or back pay: Under the law, a wrongfully terminated or dismissed person cannot get both damages and reinstatement at one and the same time. It must be one or the other. In the case where an order of reinstatement is made the claim that the employee could make would be only for salary and not damages for wrongful dismissal, Devlin in Ridge v Baldwin in 1963.

The confusion of the Nigerian courts also reared its head in Eperokun $\mathrm{v}$ University of Lagos where the Supreme Court directed that in computing the arrears of salary due the appellant it should be taken into account that he was gainfully employed during part of the period. Similar pronouncement was made in Okongwu v NNPC in 1989. However, in Bakare v Lagos State Civil Service Commission the appellant was awarded his full back pay notwithstanding that he refused to report to his new duty post for over a year before he was unlawfully dismissed. Similarly, in CBN and Ors versus Mrs. Agnes M. Igwillo (substituted for Dr. Victor Igwilo) the court ordered payment of arrears of salary from date of dismissal till date of death of the deceased.

\section{CONCLUSION}

In this treatise, researchers have seen the reluctance of the courts in giving an order reinstatement to private employee, their befuddlement and confusion in the award of this privilege to employees in the public sectors. Really, one could state that the position of the law is that the employment that is spiced with statutory flavour is only those pronounced by the court to be so.

Researchers advocated that the courts should be more liberal in making the order of reinstatement in the private employment as well because: dismissal in most cases means more than a loss of a particular job but a loss of opportunity to pursue one's profession and a bar on one future activity. Thus, damages are hardly an adequate remedy. The affected person may ask for a hearing to clear his name. Reinstatement is the remedy for combating unfair labour practice such as employer short charging loyal employee by terminating their employment a few years before they are due for pension and gratuity. For instance the courts lamented in Abalogu $v$ Shell Petroleum Devt. Company Ltd. In fact, the dictum of the trial judge is apt here:
I am in deep sympathy with the plaintiff whose appointment was terminated by the defendant barely 2 years before attaining retirement age and after serving the defendant satisfactorily and meritoriously (emphasis mine) for over 23 years but exhibit D that which governs his contract of service with the defendant renders the court impotent as far as the relief claimed by him are concerned

Despite this, all the courts, starting from the trial court-court of first instance up to the apex court the Supreme Courts refused to put on their equitable garbs to reject this injustice. His only entitlement was a mere 3 months salary in lieu of notice as per the terms of the contract. Researchers prefer the ruling of the Indian Supreme Court in Hindustan Times v Industrial Tribunal in 1963 where it was held improper to deprive an employee of gratuity he has earned because of his dismissal for misconduct. They reasoned that rather if any employee is dismissed for misconduct which has resulted into financial loss to his employer, the amount lost should be deducted from the gratuity due. The decision of the Indian Court seem just while the decision in Abalogun is considered as the triumph of law over justice. It is the contention in this treatise that even if the employer is unwilling to reinstate Abalogun to the employ, the court should have awarded him a hefty damages including his pension, gratuity and general damages by invoking and relying on a liberal life expectancy principle. Researchers have also exhaustively stated in this treatise that the parties to the contract of employment are in no way equal thus the dichotomy of master-servant and those with statutory flavour and special status be blurred.

Researchers recommend a complete overhaul of the Nigerian labour law and industrial relations system with the promulgation of new laws akin to the English Equal Right Act in 1961, the introduction of unfair dismissal and the blurring of the private/public sector dichotomy. It is noteworthy to state that the new Pension Reform Act CAP P4 LFN in 2004 is a step in the right direction, as the employer would be unable to deny their terminated or dismissed staff their due pension and gratuity as they used to do.

In the final analysis, it is the position that reinstatement should be ordered where it is just and equitable to do so and where it would not create a friction or hurt the employer if the dismissed staff is reinstated. However, where reinstatement is not possible or is not practicable, sufficient damages to start a new life especially once there is no misconduct on the employee's part. Researchers also state that the benefit enjoyed by public servants be extended to the private sector. After 
all what is good for the goose is also good for the gender. Consequently, the facts and circumstances of each case should be the basis upon which judgment is handed down by the court.

\section{REFERENCES}

Adeogun, A.A., 1986. From Contract to Status in Quest for Security. Lagos University Press, Lagos, Pages: 8.

Animashaun, O. and O. Shabi, 2009. Fundamentals of Industrial Relations: Issues and Theories. Hybrid Consult Lagos, Nigeria, pp: 21-22.

Animashaun, O., 2007. Casualisation and casual employment: Beyond contract. Labour Law Rev., 114: 16-16.
Animashaun, O., 2008. Unfair dismissal, a novel idea in the Nigerian employment law? Labour Law Rev., 2: $1-17$.

Cartey, H., 1989. Dismissed employees: The search for a more effective range of remedies. Modern Law Rev., 52: $449-468$

Chianu, E., 2006. Employment Law. Bemicov Publishers, Akure, Pages: 519.

Emiola, A., 2000. Nigerian Labour Law. Emiola Publisher Ltd., Ogbomoso.

Ipaye, A., 1992. The suspended employee under Nigerian law. Justice, 3: 62-62.

Malcolm, S., 2003. Employment Law. Longman Publisher, London, Pages: 174. 